\title{
THE GEOSTATIONARY ORBIT \\ IN THE LIGHT OF THE COMMON HERITAGE OF MANKIND (INTERNATIONAL LEGAL ASPECTS)
}

\author{
Siavash Mirzaee \\ Peoples' Friendship University of Russia, Moscow, Russian Federation
}

\begin{abstract}
Background/Objectives: since the geostationary orbit, is a limited resource located in the outer space, it seems necessary to regulate its use in order to avoid conflicts. In this article, the concept of common heritage of mankind will be examined as an instrument to address questions related to the fair use of this natural resource by developing and developed countries. Methods: the author used scientific methodological approach which facilitates determining the whole canvas of the research, identifying the main aspects and concepts of the study. The research used scientific methods of cognition, i.e. analysis, dialectics and synthesis, the method of generalization and system-structural method. Results: in this article, the author examines the concept of common heritage of mankind and its principles in the field of the geostationary orbit and presents a functional model to administer its affairs. Applications/Improvements: by declaring the geostationary orbit as common heritage of mankind, it would be possible to use them as an instrument to filling the gap between developing and developed countries concerning use of the orbit.

Key words: geostationary orbit, common heritage of mankind, outer space, radio frequency, developing countries, Bogota Declaration, ITU, natural recourses.
\end{abstract}

УДК 341(96)

ББК 67.404

\section{ИСПОЛЬЗОВАНИЕ ГЕОСТАЦИОНАРНОЙ ОРБИТЫ В СВЕТЕ КОНЦЕПЦИИ «ОБЩЕЕ НАСЛЕДИЕ ЧЕЛОВЕЧЕСТВА» (МЕЖДУНАРОДНО-ПРАВОВЫЕ АСПЕКТЫ)}

\footnotetext{
Сиваш Мирзаи

Российский университет дружбы народов, г. Москва, Российская Федерация

Аннотация. Цели: поскольку геостационарная орбита является ограниченным ресурсом, который находится в космическом пространстве, то представляется необходимым регулировать его использование в соответствии с международным правом, чтобы избежать вероятных конфликтов. В этой статье понятие общего наследия человечества будет рассматриваться как инструмент для решения вопросов, связанных со справедливым использованием этого природного ресурса развивающимися и развитыми государствами.
} 
Методы: в статье использован научно-методический подход, который облегчает проведение всего исследования, выявляет основные аспекты и концепции исследования. В исследовании использовались научные методы познания: анализ, диалектика, синтез, метод обобщения и системно-структурный метод. Результаты: в этой статье автор рассмотрел концепцию общего наследия человечества, принципы реализации этой концепции и применил их к международно-правовому статусу геостационарной орбиты и предложил функциональную правовую модель решения существующей проблемы. Применимость: объявив геостационарную орбиту общим наследием человечества, можно было бы использовать ее мирным образом и развивающимися, и развитыми государствами мира.

Ключевые слова: геостационарная орбита, общее наследие человечества, космическое пространство, радиочастота, развивающиеся государства, Боготская декларация, МСЭ, природные ресурсы.

\section{Introduction}

Given that space technologies are considered as indicators of countries development and advancement, the efforts to conquer this arena began first by developed countries and then the developing countries. Due to the limited scope of some domains in the outer space, these efforts led to the states rivalry in this area. These competitions provided the ground for the emergence of international disputes over the right to use them.

In 1962, for the first time, the Telstar satellite was placed in the Low Earth Orbit (LEO) and brought a new era of human explorations for all the world. Since then, the importance of using the orbits around the earth came to the light for everyone and States and nations became aware of the benefits of these orbits for use in the issues of television, telecommunication, remote sensing, meteorology, navigation, etc.The United Nations member States ratified the Outer Space Treaty in 1967, according to which, the resources of the outer space were supposed to belong to all. As the Earth's orbits are in the outer space and part of the limited resources, it matters to utilize these orbits based on a regulated approach to avoid conflicts and disputes regarding their use. Hence, the developing countries will also have a share of these orbits.

Considering that the geostationary orbit appears to be the most important Earth's orbit, we will refer to the issue of its use in this paper. In addition, we will assess the ability to apply the concept of the common heritage of mankind to this limited and valuable resource.

\section{Methodology and Documentary Basis of the Research}

In this article, we use international law resources, rely on international documents about the Geostationary Orbit and the common heritage of mankind principle, deploy argumentative, deductive and analytical discussions, employ deduction, induction and analogy, make use of library sources, and utilize valid procedures related to the research topic to research at our best. In connection with documentary basis of this research, there are some global documents such as the 1967 Outer Space Treaty, the Treaty Governing the Activities of States on the Moon and Other Celestial Bodies 1979, and the 1977 Bellagio Draft Treaty.

\section{Discussion}

\subsection{The Common Heritage of Mankind}

When Poly metallic nodules were found in deep seabed in the end of 19th century, and became abundant, scientific and technical methods were applied to establish legal regime of common heritage of mankind. Arvid Pardo suggested common heritage of mankind concept on 1 November 1967, in the United Nations General Assembly. He said that the seabed and ocean floor and subsoil are not assets of any country and belong to all human who lived on earth. His view caused to start negotiations on the United Nations Convention on the Law of the Sea ${ }^{1}$. Agreement Governing the Activities of States on the Moon and Other Celestial Bodies ${ }^{2}$ also stated that the moon and its resources belong to all of human $[7$, p. 506].

\subsection{Principles of the Common Heritage of Mankind}

The concept of the common heritage of mankind can be considered to consist of four distinguishable but intertwined principles. The 


\section{МЕЖДУНАРОДНОЕ ПРАВО И СРАВНИТЕЛЬНОЕ ПРАВОВЕДЕНИЕ}

main principles making up the concept are the following: (1) The requirement that areas outside the limits of national jurisdiction may be used for peaceful purposes only; (2) The requirement that areas beyond the limits of national jurisdiction may not be subjected to sovereignty; (3) The requirement that the use of such areas as well as the exploration and exploitation of their resources have to be carried out for the benefit of all mankind; (4) And the requirement that some type of international machinery is necessary in order to regulate and supervise the use of the areas and their resources [6, p. 104].

\subsection{The Definition and Importance of Geostationary Orbit}

The geostationary orbit is a circular synchronous orbit above the earth's equator. The geostationary orbit is a unique natural resource and a satellite launched into this orbit is able to complete a circle around the earth in approximately twenty four hours. Accordingly, the orbital movement of the satellite is synchronous to the earth's rotation and the satellite becomes located in a fixed position in outer space that is invaluable from a communication standpoint. A satellite that is launched into the geostationary orbit is called a geostationary satellite [10, p. 31]. In 1971, the International Telecommunication Union ${ }^{3}$ held the World Administrative Radio Conference ${ }^{4}$ for Space Telecommunication, where a 'geostationary satellite' was defined as: a satellite, the circular orbit of which lies in the plane of the Earth's equator and which turns about the polar axis of the earth in the same direction and with the same period as those of the earth's rotation 5 .

In spite of its name, a geostationary satellite is not stationary at all. Its stationary position is a relative concept and it appears stationary to an observer on the earth's surface, because it rotates at the same speed as the earth. Due to their fixed positions in the sky, geostationary satellites become stationary antennas for transmission of signals between stations, whether on the earth's surface or in outer space. They have the ability to relay signals to ground stations within their arc of visibility. These satellites are used for services, such as radio navigation, space research, satellite-to-home broadcasting and the provision of communications between fixed ground stations.

The low earth orbit satellites are the first communication satellites, and they are able to transmit signals for a short time only. Thus, a way had to be found for establishing a permanent satellite communications system and that's why the issue of the geostationary orbit was raised. The benefit of utilization of the geostationary orbit instead of other orbits is related to the fact that three such satellites would be adequate to cover the entire surface of the earth, with the exception of high altitude regions, hence making the geostationary orbit the most desirable orbit for telecommunication surfaces. The geostationary orbit is also the only orbit capable of providing continuous contact with ground station via a single satellite. The geostationary orbit, as stated in Article 33(2) of the ITU Convention of 1973, is a physically limited natural resource, as once a satellite occupies a place in the orbit it precludes the use of the same location by any other party $[12$, p. 26].

\subsection{The Bogota Declaration ${ }^{6}$}

The developing States feared that the occupancy of geostationary slots by the developed States could prevent them from using the orbit resource in the future. These fears, were manifested publicly in the 1976 Bogota Declaration. By means of this Declaration, eight equatorial developing States claimed sovereignty rights over the parts of the geostationary orbit lying over their respective territories. In making their request, the equatorial States also called for international administration of the rest of the geostationary orbit and suggested how to handle the environmental aspects related to its use. The basis of the declarants' reasoning was the consideration that the existence and the peculiar features of the geostationary orbit depended exclusively on its relation to gravitational phenomena generated by the Earth. As a consequence, the geostationary orbit should not be considered a part of outer space, but rather part of national territory. Since each nation has the right to control its own natural resources, the equatorial States argued the portions of geostationary orbit was controlled by those nations having territory directly underneath. The 
declarants' position in this respect was rather weak, because gravitation is not generated by the equatorial States only and, moreover, the Earth's gravitation determines every possible orbit. The Bogota Declaration, although it received some support from other equatorial nations, was ultimately rejected by both developed and developing States. Space-faring States affirmed that the declarants' arguments were weak and that the equatorial States could not physically enforce their claims. Moreover, the request for sovereignty rights over parts of the geostationary orbit was in contrast with the non-appropriation principle set forth in Article II of the 1967 Outer Space Treaty [11, p.177].

\subsection{Common Heritage of Mankind's Principles and Geostationary Orbit}

After the 1992 WARC the regime of equitable access is governing the geostationary orbit. In this section, the applicability of the common heritage of mankind to this orbit will be discussed by examining it's principles within this natural resource.

\subsubsection{Principle of Peaceful Use}

Since the geostationary orbit located in the outer space, the principle of peaceful use is applicable to this resource according to the 1967 Outer Space Treaty. Applying this principle to the geostationary orbit is vital, because it will prevent likely conflicts over non-peaceful utilization of the orbit. Besides, throughout the history of the common heritage of mankind, the use of international spaces for peaceful purposes has been a very important component of the common heritage of mankind concept. Hence, since this orbit situated in an international space, this principle should be applicable to it.

\subsubsection{Principle of Non-Exclusive Use}

The non-exclusive use of the geostationary orbit, as a part of the outer space environment, is well established in the 1967 Outer Space Treaty and in the decisions of the WARC meetings. According to the WARC 1979 resolution, for example, priority of registration would no longer grant permanent priority upon the use of the slots or bands concerned, abrogating, therefore, the "first come-first served" rule. Nonetheless, as satellites preclude the use of the same position until an unspecified time, this amounts somehow to a concealed de facto appropriation. Therefore the existence of the de jure prohibition of appropriation of the geostationary orbit does not preclude the use of orbital positions to be used exclusively for national and private benefits [2, p. 273]. The allotment plan adopted at World Administrative Radio Conference 1992 is a right step in restricting unlimited access. The plan gives each ITU member appropriate positions in the orbital-spectrum to be used for domestic communication [3, p. 215]. Nevertheless, in practice there are many provisions which are inconsistent with the common heritage of mankind philosophy. To correct this, durational limits of some 30 years must be imposed on allotments. Secondly, developing States with no space technology sell their orbital positions just as property on the market $[8$, p. 25$]$.

\subsubsection{Principle of Benefit Sharing}

Telecommunication via satellites is a very lucrative business. Thus, frequency bands are the most precious resource of the telecommunications age. The overwhelming majority of satellites are owned and run by a handful of technologically advanced States, whereby they earn very significant amount of money. Accordingly, the money goes to a few rental companies and to the rulers of those countries, not the peoples. According to a common heritage regime, an authority to be set up should supervise that all peoples benefit from orbital slots and monies paid go to a Common Heritage Fund to be distributed to those who are really in need and for the protection of other common heritages [9, p. 211].

\subsubsection{Principle of International Machinery}

As the ITU does not have coercive means of enforcement and the International Frequency Registration Board, a sub-unit of this organization, does not have power to enforce illegal transmission and refuse registration [4, p. 660], this increases the need to establish a strong authority or to consolidate the management of all the common heritage of mankind resources situated in outer space [1]. 


\section{МЕЖДУНАРОДНОЕ ПРАВО И СРАВНИТЕЛЬНОЕ ПРАВОВЕДЕНИЕ}

Without a strong institutional mechanism to lay the binding rules and enforce, it is highly difficult to set up a common heritage of mankind regime satisfactory for all sides concerned. As congestion becomes an imminent reality, international management, in the interest of all States and future generations, is becoming inevitable. In the case of the geostationary orbit, international management of the orbit to achieve equitable distribution of limited positions is the most important aspect of the common heritage of mankind [5, p. 430].

\section{Conclusion}

Since the satellite launching technology to the geostationary orbit is at the disposal of a limited number of developed countries, it is not possible to use the slots for these orbits for countries that do not have such a technology and some of the developing countries. Although the ITU has determined the quota of countries to use the orbit according to its chart, but the countries lacking these technologies cannot use their orbital share. The ITU has also set a deadline for using these slots that has turned into a leverage for developing countries, which could lead to a denial of the right of these countries. Accordingly, a review of the rules established by the ITU regarding the geostationary orbit seems to be essential. As mentioned, applying the common heritage of mankind to the geostationary orbit has no theoretical problem, and they are compatible with the nature of the geostationary orbit and can solve the related issues. Relying on its principles, the equal opportunities for all countries, including developing and developed ones, would become possible. In addition, establishing a stewardship authority on behalf of all nations, just as one for the seabed, can appears as a feasible and experienced solution through which the justice can be established among all the nations.

\section{NOTES}

${ }^{1}$ Adopted on 10 December 1982, entered into force on 16 November 1994.

${ }^{2}$ Adopted on 18 December 1979, entered into force on 11 July 1984.
${ }^{3}$ Hereinafter 'ITU'.

${ }^{4}$ Hereinafter 'WARC'.

${ }^{5}$ Paragraph 84BG, Annex 1, Revision of Article 1 of the Radio Regulation, 23 United States Treaty Series 1527.

${ }^{6}$ Adopted on 3 December 1976.

\section{REFERENCES}

1. AbashidzeA.Kh., Solntsev A.M., Chernykh I.A. To the $150^{\text {th }}$ anniversary of the establishment of the International Telecommunication Union - a Specialized Agency of the United Nations. Eurasian Journal of Law, 2015, no. 7, pp. 55-61. (in Russian)

2. Baslar K. The Concept of the Common Heritage of Mankind in International Law. Martinus Nijhoff Publishers, 1998, vol. 30.

3. Christol C.Q. The Legal Status of the Geostationary Orbit in the Light of the 1985-88 Activities of the ITU. Proceedings of the Thirty-Second Colloquium on the Law of Outer Space, 1989.

4. Herter C.A. The Electromagnetic Spectrum: A Critical Natural Resource. Natural Resources Journal, 1985, vol. 25 (3).

5. Kiss A. The Common Heritage of Mankind: Utopia or Reality? International Journal, 1985, vol. 40 (3).

6. Mirzaee S., Abashidze A.Kh., Solntsev A.M. The Concept of Common Heritage of Mankind in the Advisory Opinion of 1 February 2011 by the International Tribunal for the Law of the Sea. Journal of Advanced Research in Law and Economics, 2017, vol. 8 (2).

7. Mirzaee S. Outer Space and Common Heritage of Mankind: Challenges and Solutions. RUDN Journal of Law, 2017, vol. 21 (1).

8. Riddick D. Why Does Tonga Own Outer Space? Air \& Space L., 1994, vol. 19.

9. Stone Ch.D. The Gnat is Older than Man: Global Environment and Human Agenda. Princeton University Press, 1995.

10. Talaie F. Legal Issues concerning the Radio Frequency Spectrum and the Geostationary Satellite Orbit. Austl. International Journal, 1998.

11. Tronchetti F. The Exploitation of Natural Resources of the Moon and Other Celestial Bodies. Brill, 2009.

12. Wihlborg C.G., Per Magnus W. Outer Space Resources in Efficient and Equitable Use: New Frontiers for Old Principles. The Journal of Law and Economics, 1981, vol. 24 (1). 


\section{Information about the Author}

Siavash Mirzaee (Iran), Postgraduate Student, Department of International Law, Peoples' Friendship University of Russia, Miklukho-Maklaya St., 6, 117198 Moscow, Russian Federation, siavash.mirzaei1988@gmail.com.

\section{Информация об авторе}

Сиваш Мирзаи (Иран), аспирант кафедры международного права, Российский университет дружбы народов, ул. Миклухо-Маклая, 6, 117198 г. Москва, Российская Федерация, siavash.mirzaei1988@gmail.com. 